\title{
KINERJA KEUANGAN TERHADAP KEMAMPUAN BERKELANJUTAN PERUSAHAAN
}

\author{
Kurnia Octha Saputri \\ kurniaocthasaputri@gmail.com \\ Fakultas Ekonomi dan Bisnis, Universitas Telkom
}

diterima: 21/5/2018; direvisi: 20/8/2018; diterbitkan: 30/4/2019

\begin{abstract}
This study aims to investigate the financial performance and sustainable company ability and investigate the effect of financial performance as measured by by profitability (ROA), capital adequacy $(C A R)$, operational performance efficiency (BOPO), liquidity ( $F D R)$, and non performing financing $(N P F)$, on the sustainable company ability as measured by the FSR at Sharia Commercial Bank in Indonesia for the period 2012-2016. The sample used in this research is 11 Sharia Commercial Banks. The sample selection technique used is purposive sampling. Methods of data analysis using panel data regression analysis with 5\% significance. The result of t test shows that capital adequacy has significant positive effect, meanwhile profitability operational performance efficiency, liquidity, and non performing financing has significant negative effect. The result of $F$ test shows that simultaneously the financial performance has significant effect on corporate sustainable capability with adjusted $R^{2}$ of 0.581292 .
\end{abstract}

Keywords: profitability; capital adequacy; operational performance efficiency; liquidity; non performing financing; corporate sustainable capability

\begin{abstract}
Abstrak
Penelitian ini bertujuan untuk menginvestigasi kinerja keuangan dan kemampuan berkelanjutan perusahaan serta menginvestigasi pengaruh kinerja keuangan yang diukur dengan profitabilitas (ROA), kecukupan modal (CAR), efisiensi kinerja operasional (BOPO), likuiditas (FDR), dan pembiayaan bermasalah (NPF), terhadap kemampuan berkelanjutan perusahaan yang diukur dengan FSR pada Bank Umum Syariah di Indonesia periode 2012-2016. Sampel yang digunakan dalam penelitian ini sebanyak 11 Bank Umum Syariah. Teknik pemilihan sampel yang digunakan yaitu purposive sampling. Metode analisis data menggunakan analisis regresi data panel dengan signifikansi 5\%. Hasil penelitian uji t menunjukkan bahwa kecukupan modal berpengaruh positif signifikan, sedangkan profitabilitas, efisiensi kinerja operasional, likuiditas, dan pembiayaan bermasalah berpengaruh negatif signifikan. Hasil penelitian uji $\mathrm{F}$ menunjukkan bahwa secara simultan kinerja keuangan berpengaruh signifikan terhadap kemampuan berkelanjutan perusahaan dengan adjusted $\mathrm{R}^{2}$ sebesar 0,581292 .
\end{abstract}

Kata Kunci: profitabilitas; kecukupan modal; efisiensi kinerja operasional; likuiditas; pembiayaan bermasalah; kemampuan berkelanjutan perusahaan 


\section{PENDAHULUAN}

Keberadaan lembaga bank termasuk Bank Umum Syariah saat ini sangat diperlukan untuk mengembangkan perekonomian atau untuk stabilitas perekonomian negara, baik sebagai tempat investasi dana atau sebagai tempat untuk memperoleh dana. Oleh karena itu, karena adanya kebutuhan sebuah negara akan lembaga bank maka bank harus dipahami sebagai usaha yang dapat melangsungkan usahanya (going concern) dimana sebuah perusahaan dibuat bukan hanya untuk kepentingan sesaat saja (Santoso et al., 2016).

Bank Umum Syariah di Indonesia memiki potensi yang besar untuk tumbuh karena Indonesia dikenal sebagai negara dengan penduduk muslim terbesar, oleh karena itu sudah selayaknya Indonesia menjadi pelopor dan kiblat dalam pengembangan di bidang syariah. Data terakhir menunjukkan sampai bulan Desember 2016, perkembangan jumlah Bank Umum Syariah terdapat pada Gambar 1.

Berdasarkan Gambar 1 tentang perkembangan jumlah Bank Umum Syariah di Indonesia dari tahun 2012 hingga 2016 mengalami peningkatan, yang semula hanya ada 11 bank pada tahun 2012 menjadi 13 bank pada tahun 2016. Peningkatan ini diharapkan dapat memberikan masyarakat Indonesia kemudahan dalam mendapatkan layanan yang ada pada Bank Umum Syariah. Kemudahan tersebut akan berdampak pada Bank Umum Syariah itu sendiri karena jika masyarakat lebih mudah mendapatkan layanan tersebut maka hal tersebut akan menambah efektifitas dari Bank Umum Syariah karena dapat meningkatkan layanan dan penyaluran pembiayaan bank syariah kepada masyarakat yang akan menyebabkan pendapatan yang meningkat bagi Bank Umum Syariah, sehingga kemampuan Bank Umum Syariah untuk tetap berkelanjutan juga akan meningkat dan kelangsungan usaha Bank Umum Syariah akan semakin membaik.

Salah satu bukti keberhasilan kinerja Bank Umum Syariah dapat dilihat dari kemampuan berkelanjutan perusahaan pada Bank Umum Syariah di masa yang akan datang. Kemampuan berkelanjutan perusahaan pada Bank Umum Syariah dapat diukur dengan menggunakan rasio keberlanjutan keuangan atau Financial Sustainability Ratio (FSR). Keberlanjutan keuangan dikatakan baik jika nilainya lebih besar dari $100 \%$, artinya bahwa total pendapatan harus lebih besar dari total biaya yang dikeluarkan (Ledgerwood, 2000).

Berdasarkan Gambar 2 dapat dilihat bahwa kondisi kemampuan berkelanjutan perusahaan yang diukur dengan FSR pada Bank Umum Syariah mengalami penurunan pada tahun yang diteliti, Menurut Kania (2015) yang disampaikan oleh ketua Pengembangan Bisnis Asosiasi Bank Syariah Indonesia bahwa profitabilitas bank syariah masih dibawah realisasi, faktor yang melatarbelakangi penurunan laba tersebut adalah biaya pencadangan yang naik karena disebabkan oleh peningkatan CKPN
(Cadangan Kerugian Penurunan Nilai) dan pendapatan operasional yang tidak tumbuh signifikan, sehingga hal ini akan mempengaruhi tingkat efisiensi kinerja operasional yang tinggi sehingga kemampuan berkelanjutan perusahaan akan rendah karena apabila biaya meningkat dan pendapatan tidak tumbuh signifikan maka akan berimbas pada kelangsungan usaha yang menurun, dan menurut Suryowati (2017) seperti yang dikatakan Direktur Perbankan Syariah OJK bahwa pertumbuhan pembiayaan perbankan syariah mengalami peningkatan tetapi peningkatan ini tidak disertai dengan kinerja yang positif, sehingga pembiayaan bermasalah akan tinggi dan apabila pembiayaan itu tinggi dan kinerjanya menurun maka kemampuan berkelanjutan perusahaan dan kelangsungan usaha semakin tidak membaik. Selain itu, menurut Himawan (2015) tingkat kecukupan modal perbankan syariah masih rendah, hal ini disebabkan oleh perbankan syariah kesulitan untuk masuk lebih ke dalam pasar keuangan karena modal yang masih minim dan dana biaya yang mahal (deposito syariah) dibandingkan Bank Umum Konvesional. Oleh karena itu, walaupun Indonesia dikenal dengan penduduk muslim terbesar di dunia tetapi minat masyarakat masih sangat rendah terhadap Bank Umum Syariah karena masyarakat Indonesia lebih memilih yang menguntungkan bagi mereka dan hal ini yang berimbas pada kemampuan berkelanjutan perusahaan yang menurun.

Berdasarkan fenomena yang telah dijelaskan dan penelitian terdahulu yang berhubungan dengan kemampuan berkelanjutan perusahaan yang diukur dengan FSR yaitu penelitian Almilia et al. (2009), Fadhilla (2011), Wahyuni dan Fakhruddin (2014), Sarwono dan Sunarko (2015), Notoatmojo dan Rahmawaty (2016), Santoso et al. (2016) pada dasarnya terdapat banyak faktor yang mempengaruhi kemampuan berkelanjutan perusahaan seperti profitabilitas, kecukupan modal, efisiensi kinerja operasional, likuiditas, pembiayaan bermasalah, dan makro ekonomi. Berdasarkan beberapa variabel yang mempengaruhi kemampuan berkelanjutan perusahaan tersebut, penulis menemukan bahwa pada profitabilitas, kecukupan modal, efisiensi kinerja operasional, likuiditas, dan pembiayaan bermasalah masih ditemukan hasil yang tidak konsisten.

Pengukuran profitabilitas yang relevan digunakan dalam Bank Umum Syariah adalah Return On Asset (ROA) dikarenakan total aset Bank Umum Syariah banyak diperoleh dari nasabah (dana pihak ketiga). Berdasarkan penelitian terdahulu terdapat hasil yang tidak konsisten mengenai pengaruh ROA terhadap kemampuan berkelanjutan perusahaan (FSR). Pada hasil penelitian Notoatmojo dan Rahmawaty (2016) menghasilkan ROA yang berpengaruh positif signifikan terhadap FSR, sedangkan pada penelitian Wahyuni dan Fakhruddin (2014) menghasilkan bahwa ROA berpengaruh negatif signifikan terhadap FSR, berbeda dengan hasil penelitian Almilia et al. (2009), Fadhilla (2011), serta Sarwono dan Sunarko (2015) yang 
menghasilkan bahwa ROA tidak berpengaruh terhadap FSR. ROA yang berpengaruh positif signifikan artinya semakin besar nilai ROA maka semakin besar tingkat kemampuan berkelanjutan perusahaan atau semakin kecil nilai ROA maka semakin kecil tingkat kemampuan berkelanjutan perusahaan, hal ini menunjukkan bahwa semakin besar keuntungan yang dicapai bank dan semakin efisien bank dalam menggunakan aset untuk menghasilkan laba sehingga memberikan kontribusi yang cukup besar bagi kemampuan berkelanjutan perusahaan, atau sebaliknya. ROA yang berpengaruh negatif signifikan artinya semakin kecil nilai ROA maka semakin besar tingkat kemampuan berkelanjutan perusahaan yang diukur dengan menggunakan FSR, hal ini menunjukkan total aset yang dimiliki Bank Umum Syariah besar sehingga hasil perbandingan antara laba dan total asetpun mengecil. Total aset yang besar mengindikasikan bahwa komponen pembentuk total aset itu pun besar, seperti piutang bagi hasil dan aset pembiayaan. Piutang bagi hasil dan pembiayaan merupakan komponen dari pendapatan finansial dalam FSR sehingga bisa mengakibatkan nilai dari FSR pun membesar, atau sebaliknya. Penelitian ini mengindikasikan bahwa profitabilitas (ROA) berpengaruh positif signifikan terhadap kemampuan berkelanjutan perusahaan (FSR).

Pengukuran kecukupan modal yang relevan digunakan dalam Bank Umum Syariah adalah Capital Adequacy Ratio (CAR). CAR merupakan rasio modal yang dapat memberikan potensi. Bank Umum wajib menyediakan modal minimum sebesar $8 \%$ dari Aktiva Tertimbang Menurut Risiko (ATMR) (BI, 2013). Berdasarkan penelitian terdahulu terdapat hasil yang tidak konsisten mengenai pengaruh CAR terhadap kemampuan berkelanjutan perusahaan (FSR). Pada hasil penelitian Almilia et al. (2009), Wahyuni dan Fakhruddin (2014), Sarwono dan Sunarko (2015), dan Santoso et al. (2016) menghasilkan bahwa CAR berpengaruh positif signifikan terhadap FSR, sedangkan penelitian Fadhilla (2011) serta Notoatmojo dan Rahmawaty (2016) menghasilkan bahwa CAR tidak berpengaruh terhadap FSR. CAR yang berpengaruh positif signifikan artinya semakin besar nilai CAR maka semakin besar tingkat kemampuan berkelanjutan perusahaan atau semakin kecil nilai CAR maka semakin kecil tingkat kemampuan berkelanjutan perusahaan yang diukur dengan menggunakan FSR, hal ini menunjukkan bahwa kemampuan bank semakin baik untuk menanggung risiko dari setiap aktiva produktif yang berisiko dan bank semakin mampu membiayai kegiatan operasional, ketika ATMR rerata bank naik maka peroleh pembiayaan dari nasabah pun bertambah dan membuat pendapatan juga akan bertambah dan modal juga akan mengalami kenaikan. Penelitian ini mengindikasikan bahwa kecukupan modal (CAR) berpengaruh positif signifikan terhadap kemampuan berkelanjutan perusahaan (FSR).
Pengukuran efisiensi kinerja operasional yang relevan digunakan dalam Bank Umum Syariah adalah Biaya Operasional terhadap Pendapatan Operasional (BOPO). BOPO merupakan perbandingan antaran biaya operasional terhadap pendapatan operasional. Berdasarkan penelitian terdahulu terdapat hasil yang tidak konsisten mengenai pengaruh BOPO terhadap kemampuan berkelanjutan perusahaan (FSR). Pada hasil penelitian Fadhilla (2011), Wahyuni dan Fakhruddin (2014), Sarwono dan Sunarko (2015), serta Notoatmojo dan Rahmawaty (2016) menghasilkan bahwa BOPO berpengaruh negatif signifikan terhadap FSR, berbeda dengan hasil penelitian Almilia et al. (2009) yang menghasilkan bahwa BOPO tidak berpengaruh terhadap FSR. BOPO yang berpengaruh negatif signifikan artinya semakin kecil nilai BOPO maka semakin besar tingkat kemampuan berkelanjutan perusahaan atau semakin besar nilai BOPO maka semakin kecil tingkat kemampuan berkelanjutan perusahaan yang diukur dengan menggunakan FSR, hal ini menunjukkan bahwa bank dapat menggunakan faktor-faktor produksinya secara maksimal dengan manajemen yang baik dan tepat sehingga dapat meningkatkan kemampuan berkelanjutan perusahaan. Penelitian ini mengindikasikan bahwa efisiensi kinerja operasional (BOPO) berpengaruh negatif signifikan terhadap kemampuan berkelanjutan perusahaan (FSR).

Pengukuran likuiditas yang relevan digunakan dalam Bank Umum Syariah adalah Financing to Deposit Ratio (FDR). FDR adalah perbandingan antara jumlah dana yang disalurkan di sisi lending dengan menggunakan dana yang dihimpun di sisi funding (Mahardika, 2015:180). Besarnya FDR ditetapkan oleh Bank Indonesia yakni di antara 78\%-92\%, dengan ketentuan itu berarti Bank Umum Syariah boleh memberikan pembiayaan melebihi jumlah dana pihak ketiga asalkan tidak melebihi 92\%, karena hal itu akan membahayakan kemampuan berkelanjutan perusahaan Bank Umum Syariah dan pasti akan membahayakan dana simpanan para nasabah penyimpan dana dari Bank Umum Syariah. Berdasarkan penelitian terdahulu terdapat hasil yang tidak konsisten mengenai pengaruh FDR terhadap kemampuan berkelanjutan perusahaan (FSR). Pada hasil penelitian Santoso et al. (2016) menghasilkan bahwa FDR berpengaruh negatif signifikan terhadap FSR, berbeda dengan hasil penelitian Wahyuni dan Fakhruddin (2014). Sarwono dan Sunarko (2015), serta Notoatmojo dan Rahmawaty (2016) yang menghasilkan bahwa FDR tidak memiliki pengaruh terhadap FSR. FDR yang berpengaruh negatif signifikan artinya semakin kecil nilai FDR maka semakin besar tingkat kemampuan berkelanjutan perusahaan atau semakin besar nilai FDR maka semakin kecil tingkat kemampuan berkelanjutan perusahaan yang diukur dengan menggunakan FSR, hal ini menunjukkan bahwa semakin tinggi nilai FDR maka akan semakin rendahnya kemampuan likuiditas Bank Umum Syariah karena jumlah dana yang diperlukan 
untuk membiayai pembiayaan menjadi semakin besar sehingga semakin rendah kemampuan berkelanjutan perusahaan. Penelitian ini mengindikasikan bahwa likuiditas (FDR) berpengaruh negatif signifikan terhadap kemampuan berkelanjutan perusahaan (FSR).

Pengukuran pembiayaan bermasalah yang relevan digunakan dalam Bank Umum Syariah adalah Non Performing Financing (NPF). NPF adalah rasio yang bisa digunakan untuk melihat risiko pembiayaan bermasalah. Berdasarkan penelitian terdahulu terdapat hasil yang tidak konsisten mengenai pengaruh NPF terhadap kemampuan berkelanjutan perusahaan (FSR). Pada hasil penelitian Almilia et al. (2009) serta Notoatmojo dan Rahmawaty (2016) menghasilkan NPF memiliki pengaruh yang negatif signifikan terhadap FSR, berbeda dengan hasil penelitian Fadhilla (2011), Sarwono dan Sunarko (2015), serta Wahyuni dan Fakhruddin (2014) yang menghasilkan bahwa NPF tidak memiliki pengaruh terhadap FSR. NPF yang berpengaruh negatif signifikan artinya semakin kecil nilai NPF maka semakin besar tingkat kemampuan berkelanjutan perusahaan atau semakin besar nilai NPF maka semakin kecil tingkat kemampuan berkelanjutan perusahaan yang diukur dengan menggunakan FSR, hal ini menunjukkan bahwa pertumbuhan pembiayaan bermasalah mengalami penurunan sedangkan total pembiayaan yang diterima besar sehingga total kerugian yang harus ditanggung oleh bank tersebut juga kecil, sehingga pendapatan yang didapat oleh besar, dan kemampuan berkelanjutan perusahaan juga akan meningkat. Penelitian ini mengindikasikan bahwa pembiayaan bermasalah (NPF) berpengaruh negatif signifikan terhadap kemampuan berkelanjutan perusahaan (FSR).

\section{METODE}

Operasionalisasi varibel ditunjukkan pada Tabel 1. Populasi dalam penelitian ini adalah Bank Umum Syariah yang di Indonesia tahun 2012-2016. Teknik yang digunakan dalam penelitian ini adalah purposive sampling yang dan diperoleh 11 unit sampel selama tahun 2012-2016 (Tabel 2).

Teknik analisis yang digunakan dalam penelitian ini adalah analisis statistik deskriptif dan regresi data panel dengan persamaan regresi data panel sebagai berikut:

$$
\mathrm{Y}_{\mathrm{it}}=\beta_{0}+\beta_{1} \mathrm{X}_{1 \mathrm{it}}+\beta_{2} \mathrm{X}_{2 \mathrm{it}}+\beta_{3} \mathrm{X}_{3 \mathrm{it}}+\beta_{4} \mathrm{X}_{4 \mathrm{it}}+\beta_{5} \mathrm{X}_{5 \mathrm{it}}+\mathrm{e}_{\mathrm{it}}
$$

\section{Keterangan:}

$\mathrm{i}=$ Jenis perusahaan

$\mathrm{t}=$ Waktu

$\beta_{0}=$ Koefisien intersep

$\beta_{1}=$ Koefisien slope

$\mathrm{Y}=$ Financial Sustainability Ratio

$\mathrm{X}_{1}=$ Return On Asset

$\mathrm{X}_{2}=$ Capital Adequacy Ratio
$\mathrm{X}_{3}=$ Biaya Operasional terhadap Pendapatan Operasional

$\mathrm{X}_{4}=$ Financing to Deposit Ratio

$\mathrm{X}_{5}=$ Non Performing Financing

\section{HASIL}

Tabel 3 menunjukkan bahwa rerata (mean) dari variabel dependen kemampuan berkelanjutan perusahaan yang diukur dengan FSR sebesar 1,4605, sedangkan standar deviasi sebesar 0,4992, itu artinya rerata lebih besar daripada standar deviasi, sehingga data tersebut tidak bervariasi atau relatif homogen (cenderung berkelompok). Nilai maksimum dimiliki oleh Maybank Syariah pada tahun 2012 sebesar 2,8202, artinya Maybank Syariah pada tahun tersebut memiliki tingkat kemampuan berkelanjutan perusahaan yang baik karena pendapatan finansial Bank Umum Syariah lebih besar dari beban finansial sehingga Maybank Syariah dapat melangsungkan usahanya dilihat dari nilai FSR. Nilai minimum dimiliki oleh Bank Victoria Syariah pada tahun 2016 sebesar 0,8591, artinya Bank Victoria Syariah harus berhati-hati karena dengan nilai kemampuan berkelanjutan perusahaan di bawah 100\% maka bank tersebut diindikasikan mengalami kebangkrutan karena beban finansial lebih besar dari pendapatan finansial.

Tabel 3 menunjukkan bahwa rerata (mean) dari variabel independen profitabilitas yang diukur dengan ROA sebesar 0,0004, sedangkan standar deviasi sebesar 0,0376, itu artinya rerata lebih kecil daripada standar deviasi, sehingga data tersebut bervariasi atau relatif heterogen (cenderung tidak berkelompok). Nilai maksimum dimiliki oleh Maybank Syariah pada tahun 2014 sebesar 0,0313 atau 3,13\%, artinya profitabilitas Maybank Syariah pada tahun tersebut terdapat pada kondisi yang baik karena pada tahun tersebut Maybank Syariah memiliki laba sebesar 3.13\% dari total aset yang dimiliki sehingga Maybank Syariah dapat mengoptimalkan penggunaan total aset dalam menghasilkan laba. Nilai minimum dimiliki oleh Maybank Syariah pada tahun 2015 sebesar -0,2245, artinya profitabilitas Maybank Syariah pada tahun tersebut tidak dalam kondisi yang baik karena Maybank Syariah tidak dapat mengoptimalkan penggunakan total aset yang dimilikinya sehingga Maybank Syariah mengalami kerugian pada tahun tersebut.

Tabel 3 menunjukkan bahwa rerata (mean) dari variabel independen kecukupan modal yang diukur dengan CAR sebesar 0,2145, sedangkan standar deviasi sebesar 0,1218, itu artinya rerata lebih besar daripada standar deviasi, sehingga data tersebut tidak bervariasi atau relatif homogen (cenderung berkelompok). Nilai maksimum dimiliki oleh Maybank Syariah pada tahun 2012 sebesar 0,6389, artinya Maybank Syariah dilihat dari kecukupan modalnya pada tahun tersebut dalam kondisi yang sehat karena jumlah modal yang dimiliki Maybank Syariah sebesar 63,89\% sehingga bank 
tersebut mampu membiayai kegiatan operasional dan memberikan kontribusi yang cukup besar. Nilai minimum dimiliki oleh Bank Syariah Bukopin pada tahun 2013 sebesar 0,1110, artinya Bank Syariah Bukopin pada tahun tersebut tidak mampu membiayai pembiayaan atau risiko dari hasil modal yang dimilikinya.

Tabel 3 menunjukkan bahwa rerata (mean) dari variabel independen efisiensi kinerja operasional yang diukur dengan BOPO sebesar 0,9308, sedangkan standar deviasi sebesar 0,2307 , itu artinya rerata lebih besar daripada standar deviasi, sehingga data tersebut tidak bervariasi atau relatif homogen (cenderung berkelompok). Nilai maksimum dimiliki oleh Maybank Syariah pada tahun 2015 sebesar 1,9260, artinya Maybank Syariah pada tahun tersebut tidak dalam kondisi yang sehat karena bank tersebut tidak mampu menekan biaya operasional yang ada sehingga berakibat pada nilai efisiensi kinerja operasional yang tinggi. Nilai minimum dimiliki oleh Bank Panin Dubai Syariah pada tahun 2012 sebesar 0,4760, artinya Bank Panin Dubai Syariah pada tahun tersebut terdapat dalam kondisi kesehatan yang baik karena bank tersebut mampu menekan biaya operasional terhadap pendapatan operasional.

Tabel 3 menunjukkan bahwa rerata (mean) dari variabel independen likuiditas yang diukur dengan FDR sebesar 0,9713, sedangkan standar deviasi sebesar 0,2072, itu artinya rerata lebih besar daripada standar deviasi, sehingga data tersebut tidak bervariasi atau relatif homogen (cenderung berkelompok). Nilai maksimum dimiliki oleh Maybank Syariah pada tahun 2012 sebesar 1,9770, artinya Maybank Syariah pada tahun tersebut terdapat dalam kondisi yang tidak sehat, karena likuiditasnya melebihi batas maksimum yang ditetapkan yaitu sebesar $92 \%$, hal ini mengindikasikan bahwa seluruh dana telah disalurkan dalam bentuk pembiayaan yang tidak diimbangi dengan total dana pihak ketiga, dan FDR sebesar 197,70\% ini berarti $100 \%$ dana telah disalurkan dalam pembiayaan dan $97,70 \%$ kelebihannya menggunakan modal bank sendiri. Nilai minimum dimiliki oleh Bank Victoria Syariah pada tahun 2012 sebesar 0,7377, artinya Bank Victoria Syariah pada tahun tersebut tidak dapat mengoptimalkan total dana pihak ketiga yang diterima menjadi total pembiayaan karena penyaluran pembiayaan hanya sebesar $73,33 \%$ dari total dana yang dihimpun, ini menyebabkan akan banyaknya dana yang menganggur.

Tabel 3 menunjukkan bahwa rerata (mean) dari variabel independen pembiayaan bermasalah yang diukur dengan NPF sebesar 0,0513 , sedangkan standar deviasi sebesar 0,0738, itu artinya rerata lebih kecil daripada standar deviasi, sehingga data tersebut bervariasi atau relatif heterogen (cenderung tidak berkelompok). Nilai maksimum dimiliki oleh Maybank Syariah pada tahun 2016 sebesar 0,4399, artinya Maybank Syariah pada tahun tersebut pada kondisi yang tidak sehat karena pembiayaan bermasalah melebihi batas maksimum yang ditetapkan yaitu sebesar 5\%, hal ini dikarenakan banyak nasabah yang mengalami pembiayaan bermasalah yang dikategorikan macet, sehingga rasio mencapai 43,99\%. Nilai minimum dimiliki oleh Bank Central Asia Syariah pada tahun 2014 sebesar 0,0010, artinya Bank Central Asia Syariah pada tahun tersebut terdapat pada kondisi yang sehat karena bank tersebut mampu menyalurkan pembiayaan secara konsisten dengan menerapkan prinsip kehati-hatian, sehingga dapat menghasilkan pembiayaan dengan tingkat risiko yang rendah.

\section{PEMBAHASAN}

Hasil uji chow (Tabel 4), menunjukkan probability (p-value) cross section F sebesar $0,0000<0,05$. Dapat diputuskan bahwa model fixed effect lebih baik daripada model common effect. Setelah uji chow selesai dilaksanakan, maka dilanjutkan dengan uji hausman (Tabel 5). Pengujian ini dilakukan untuk menentukan model yang cocok antara fixed effect atau random effect sehingga sesuai untuk penelitian yang dilakukan.

Pada dasarnya uji statistik $\mathrm{F}$ menunjukkan apakah semua variabel bebas yang digunakan dalam model mempunyai pengaruh secara simultan atau bersama-sama terhadap variabel terikat. Penelitian ini menggunakan pengujian simultan untuk menguji variabel kinerja keuangan yang diukur dengan profitabilitas (ROA), kecukupan modal (CAR), efisiensi kinerja operasional (BOPO), likuiditas (FDR), dan pembiayaan bermasalah (NPF) sebagai variabel bebas terhadap kemampuan berkelanjutan perusahaan yang diukur dengan FSR sebagai variabel terikat. Dapat diketahui hasil signifikansinya adalah sebesar $0,000000<0,05$ maka dapat disimpulkan bahwa Hol ditolak dan Ha1 diterima yang artinya profitabilitas, kecukupan modal, efisiensi kinerja operasional, likuiditas, dan pembiayaan bermasalah secara simultan berpengaruh signifikan terhadap kemampuan berkelanjutan perusahaan yang diukur dengan FSR. Berdasarkan Tabel 6 nilai Adjusted R-Squared model penelitian adalah sebesar 0,581292 atau 58,1292\%. Dengan demikian, variabel independen kinerja keuangan yang terdiri dari profitabilitas (ROA), kecukupan modal (CAR), efisiensi kinerja operasional (BOPO), likuiditas (FDR), dan pembiayaan bermasalah (NPF) dapat menjelaskan variabel dependen yaitu kemampuan berkelanjutan perusahaan yang diukur dengan FSR sebesar 58,1292\%, sedangkan sisanya $41,8708 \%$ dijelaskan oleh variabel lain.

Nilai probabilitas profitabilitas yang diukur dengan ROA adalah sebesar 0,0000 dengan koefisien regresi bernilai negatif, maka dapat disimpulkan bahwa ROA berpengaruh negatif signifikan terhadap kemampuan berkelanjutan perusahaan. ROA yang berpengaruh negatif signifikan dikarenakan ketika ROA yang dimiliki Bank Umum Syariah menurun, maka hal tersebut bisa menjadi tanda bahwasanya laba yang dimiliki perusahaan turun dan juga total aset yang 
dimilikinya besar sehingga hasil perbandingan antara laba dan total asetpun mengecil. Total aset yang besar mengindikasikan bahwa komponen pembentuk total aset itu pun besar, seperti piutang bagi hasil, pinjaman qardh dan pembiayaan karena komponen tersebut merupakan persentase utama dalam komponen pembentuk total aset. Piutang bagi hasil, pinjaman qardh dan pembiayaan juga merupakan komponen dari pendapatan finansial maka nilai FSR pun akan besar karena peningkatan dari pendapatan finansial, selain itu beban finansial yang dimiliki perusahaan persentasenya tidak sebesar peningkatan pada pendapatan finansial sehingga bisa mengakibatkan nilai dari FSR pun juga membesar.

Nilai probabilitas kecukupan modal yang diukur dengan CAR adalah sebesar 0,0042 dengan koefisien regresi bernilai positif, maka dapat disimpulkan bahwa CAR berpengaruh positif signifikan terhadap kemampuan berkelanjutan perusahaan. Hal ini menunjukkan bahwa ketika ATMR mengalami peningkatan maka perolehan pembiayaan dari nasabah pun bertambah karena aktiva yang memiliki bobot paling besar adalah pembiayaan, ketika pembiayaan meningkat maka pendapatan finansial pun juga meningkat, karena pembiayaan juga memberikan kontribusi yang besar bagi pendapatan finasial, selain itu peningkatan ATMR tidak sebesar peningkatan modal, sehingga terdapat kondisi dimana CAR meningkat dan FSR meningkat.

Nilai probabilitas efisiensi kinerja operasional yang diukur dengan BOPO adalah sebesar 0,0001 dengan koefisien regresi bernilai negatif, maka dapat disimpulkan bahwa BOPO berpengaruh negatif signifikan terhadap kemampuan berkelanjutan perusahaan. Hal ini menunjukkan semakin kecil rasio BOPO semakin besar kemampuan berkelanjutan perusahaan artinya pendapatan operasional yang didapat oleh bank meningkat karena salah satu komponen pembentuk pendapatan operasional tersebut meningkat yaitu seperti piutang bagi hasil, pinjaman qardh dan pembiayaan. Piutang bagi hasil, pinjaman qardh dan pembiayaan merupakan komponen dari pendapatan finansial.

Nilai probabilitas likuiditas yang diukur dengan FDR adalah sebesar 0,0282 dengan koefisien regresi bernilai negatif, maka dapat disimpulkan bahwa FDR berpengaruh negatif signifikan terhadap kemampuan berkelanjutan perusahaan. FDR yang berpengaruh negatif signifikan terhadap kemampuan berkelanjutan perusahaan artinya semakin tinggi nilai FDR maka akan semakin rendahnya kemampuan likuiditas Bank Umum Syariah karena jumlah dana yang diperlukan untuk membiayai pembiayaan menjadi semakin besar, sehingga hal ini memperburuk kinerja keuangan suatu bank karena bank tersebut menggunakan dana untuk penyaluran pembiayaan semakin tidak baik atau efisien.

Nilai probabilitas pembiayaan bermasalah yang dikur dengan NPF adalah sebesar 0,0005 dengan koefisien regresi bernilai negatif, maka dapat disimpulkan bahwa NPF berpengaruh negatif signifikan terhadap kemampuan berkelanjutan perusahaan. NPF yang berpengaruh negatif signifikan terhadap kemampuan berkelanjutan perusahaan artinya NPF memiliki pengaruh yang tidak searah terhadap kemampuan berkelanjutan perusahaan. Semakin kecil rasio NPF maka semakin besar kemampuan berkelanjutan perusahaan, hal ini menunjukkan bahwa pertumbuhan pembiayaan bermasalah pada tahun tersebut mengalami penurunan sedangkan total pembiayaan yang diterima besar sehingga total kerugian yang harus ditanggung oleh bank tersebut juga kecil yang mengakibat pendapatan yang didapat oleh bank semakin besar, sehingga kemampuan berkelanjutan perusahaan juga akan meningkat.

\section{KESIMPULAN}

Berdasarkan hasil penelitian statistik deskriptif, variabel kemampuan berkelanjutan perusahaan (FSR) mempunyai data yang bersifat homogen, profitabilitas (ROA) mempunyai data yang bersifat heterogen, kecukupan modal (CAR) mempunyai data yang bersifat homogen, efisiensi kinerja operasional (BOPO) mempunyai data yang bersifat homogen, likuiditas (FDR) mempunyai data yang bersifat homogen, pembiayaan bermasalah (NPF) mempunyai data yang bersifat heterogen.

Berdasarkan hasil regresi data panel, variabel independen kinerja keuangan (profitabilitas, kecukupan modal, efisiensi kinerja operasional, likuiditas, dan pembiayaan bermasalah) secara simultan berpengaruh signifikan terhadap kemampuan berkelanjutan perusahaan Bank Umum Syariah dengan nilai Adjusted R-Squared sebesar 0,581292. Secara parsial, Profitabilitas (ROA) berpengaruh negatif signifikan, kecukupan modal (CAR) berpengaruh positif signifikan, efisiensi kinerja operasional (BOPO) berpengaruh negatif signifikan, likuiditas (FDR) berpengaruh negatif signifikan, pembiayaan bermasalah (NPF) berpengaruh negatif signifikan terhadap kemampuan berkelanjutan perusahaan Bank Umum Syariah.

\section{DAFTAR PUSTAKA}

Almilia, L. S., Angraini, \& Shonhadji, N. 2009. Faktorfaktor yang mempengaruhi Financial Sustainability Ratio Pada Bank Umum Swasta Nasional Non Devisa Periode 1995-2005. Jurnal Akuntansi dan Keuangan, ISSN: 1411-0288, E-ISSN: 2338-8137, 42-52.

Bank Indonesia (BI). 2004. Surat Edaran Bank Indonesia No. 6/23/DPNP tentang Penilaian Tingkat Kesehatan Bank Umum. Retrieved September 2017, 25, from http://www.bi.go.id/id/peraturan/perbankan/Pages/ ketentuan \%20perbankan.aspx 
Bank Indonesia (BI). 2011. Surat Edaran Bank Indonesia No. 13/30/DPNP. Retrieved September 27, 2017, from http://www.bi.go.id/id/peraturan/perbankan/ Pages/SE\%20No.13-30-DPNP.as px

Bank Indonesia (BI). 2011. Surat Edaran Bank Indonesia Nomor 13/27/DPM. Retrieved September 23, 2017, from http://www.bi.go.id/id/peraturan/moneter/ Pages/se_132711.aspx

Bank Indonesia (BI). 2013. Peraturan Bank Indonesia No 3/21/PBI/2001 tentang Kewajiban Penyediaan Modal Minimum Bank Umum. Jakarta: Bank Indonesia.

Bank Indonesia (BI). 2015. Peraturan Bank Indonesia No. 03/21/PBI/2009 tentang Unit Usaha Syariah. Jakarta: www.ojk.go.id.

Bank Indonesia (BI). 2015. Peraturan Bank Indonesia No. 17/11/PBI/2015 Tentang Perubahan Atas Peraturan Bank Indonesia No. 15/15/PBI/2013 Tentang Giro Wajib Minimum Bank Umum Dalam Rupiah dan Valuta Asing Bagi Bank Umum Konvensional. Retrieved September 25, 2017, from http://www. bi.go.id/id/peraturan/ssk/Pages/pbi_171115.aspx

Darmawi, H. 2012. Manajemen Perbankan, edisi kedua. Padang: Bumi Aksara.

Fadhilla, B. A. 2011. Analisis faktor-faktor yang mempengaruhi FSR pada Bank Umum Swasta Nasional Devisa periode 2003-2009. E Journal Akuntansi Universitas Diponegoro.

Hery. 2015. Analisis Laporan Keuangan Pendekatan Rasio Keuangan. Yogyakarta: CAPS (Center of Academic Publishing Service).

Himawan, A. 2015. Inilah 7 Kendala Pertumbuhan Perbankan Syariah di Indonesia. Retrieved September 22, 2017, from http://www. suara. com/bisnis/2015/11/21/130448/inilah-7-kendalapertumbuhan-perbank an-syariah-di-indonesia

Kania, D. 2015. Retrieved from Profitabilitas Bank Umum Syariah Masih Menurun: http://www. beritasatu. com/ekonomi/322241-profitabilitas- per bankan-syariah-masih-menurun.html

Kasmir. 2012. Analisis Laporan Keuangan. Jakarta: Rajagrafindo Persada.

Ledgerwood, J. 2000. Sustainable Banking with the poor, microfinance handbook an institutional and financial perspective. Retrieved Oktober 11, 2017, from www.worldbank.org

Mahardika, D. P. 2015. Mengenal Lembaga Keuangan. Bekasi: Gramatha Publishing.

Notoatmojo, M. I., \& Rahmawaty, A. 2016. Analisis faktor-faktor yang mempengaruhi FSR pada Bank Umum Syariah di Indonesia periode 2010-2014. Jurnal Ekonomi Syariah Volumr 4, Nomor 1, Juni 2016 P-ISSN: 2355-0288, E-ISSN: 2502-8316, $20-42$.

Pandia, F. 2012. Manajemen Dana dan Kesehatan Bank, Cetakan Pertama. Jakarta: Rineka Cipta.

Santoso, J., Khairunnisa, \& Triyanto, D. N. 2016. Pengaruh Capital Adequacy Ratio, Non Performing Loan dan Loan To Deposit Ratio terhadap Financial Sustainability Ratio (Studi Empiris pada Bank Umum Swasta Nasional yang Terdaftar di BEI periode 2011-2015). E Journal Telkom University.

Sarwono, A. E., \& Sunarko, M. R. 2015. Analisis rasio keuangan terhadap FSR pada bank campuran periode 2011-2013. EKSPLORASI, Volume XXVII No. 2 - Februari 2015, 540-549.

Suryowati, E. 2017. Retrieved from IniAlasan Pembiayaan Macet Perbankan Syariah Cukup Tinggi: http:// ekonomi.kompas.com/read/2017/04/28/222515226/ ini.alasan.pembiayaan.macet.perbankan.syariah. cukup.tinggi

Umam, K. 2013. Manajemen Perbankan Syariah. Bandung: Pustaka Setia.

Wahyuni, S., \& Fakhruddin, I. 2014. Analisis faktorfaktor yang mempengaruhi Sustainability ratio perbankan syariah di Indonesia. Seminar National dan Call For Paper Program Studi Akuntansi FEB UMS, 25 Juni 2014, 113-127. 
Tabel 2. Sampel Penelitian

\begin{tabular}{ll}
\hline No & \multicolumn{1}{c}{ Bank Umum Syariah } \\
\hline 1. & PT. Bank Muamalat Indonesia \\
2. & PT. Bank Victoria Syariah \\
3. & PT. Bank BRI Syariah \\
4. & PT. Bank Jabar Banten Syariah \\
5. & PT. Bank BNI Syariah \\
6. & PT. Bank Syariah Mandiri \\
7. & PT. Bank Mega Syariah \\
8. & PT. Bank Panin Syariah \\
9. & PT. Bank Syariah Bukopin \\
10. & PT. BCA Syariah \\
11. & PT. Bank Maybank Syariah Indonesia \\
\hline
\end{tabular}

Sumber: Data yang telah diolah

Tabel 3. Hasil Pengujian Statistik Deskriptif

\begin{tabular}{lcccccc}
\hline & FSR & ROA & CAR & BOPO & FDR & NPF \\
\hline Mean & 1.4605 & 0.0004 & 0.2145 & 0.9308 & 0.9713 & 0.0513 \\
Maks & 2.8205 & 0.0313 & 0.6389 & 1.9260 & 1.9770 & 0.4399 \\
Min & 0.8591 & -0.2245 & 0.1110 & 0.4760 & 0.7377 & 0.0010 \\
Std. Dev & 0.4492 & 0.0376 & 0.1218 & 0.2307 & 0.2072 & 0.0738 \\
\hline
\end{tabular}

Sumber: Data yang telah diolah

Tabel 4. Hasil Uji Chow

Redundant Fixed Effects Tests

Equation: Untitled

Test cross-section fixed effects

\begin{tabular}{lccc}
\hline \multicolumn{1}{c}{ Effects Test } & Statistic & d.f. & Prob. \\
\hline Cross-section F & 4.734007 & $(10,39)$ & 0.0002 \\
Cross-section Chi-square & 43.710266 & 10 & 0.0000 \\
\hline
\end{tabular}

Sumber: Hasil ouput Eviews versi 9 (data yang telah diolah)

Tabel 5. Hasil Uji hausman

Correlated Random Effects - Hausman Test
Equation: Untitled
\begin{tabular}{lccc} 
Test cross-section random effects & & \\
\hline Test Summary & Chi-Sq. Statistic & Chi-Sq. d.f. & Prob. \\
\hline Cross-section random & 7.973762 & 5 & 0.1577 \\
\hline
\end{tabular}

Sumber: Hasil ouput Eviews versi 9 (data yang telah diolah)
Tabel 6. Hasil Pengujian Random Effect Model

Dependent Variable: FSR

Method: Panel EGLS (Cross-section random effects)

Date: 11/20/17 Time: 15:40

Sample: 20122016

Periods included: 5

Cross-sections included: 11

Total panel (balanced) observations: 55

Swamy and Arora estimator of component variances

\begin{tabular}{|c|c|c|c|c|}
\hline Variable & Coefficient & Std. Error & t-Statistic & Prob. \\
\hline $\mathrm{C}$ & 3.287076 & 0.471963 & 6.964687 & 0.0000 \\
\hline ROA & -11.75842 & 1.979881 & -5.938950 & 0.0000 \\
\hline CAR & 1.479595 & 0.493057 & 3.000863 & 0.0042 \\
\hline $\mathrm{BOPO}$ & -1.393353 & 0.315879 & -4.411026 & 0.0001 \\
\hline FDR & -0.630363 & 0.278721 & -2.261627 & 0.0282 \\
\hline NPF & -3.388069 & 0.915367 & -3.701324 & 0.0005 \\
\hline \multicolumn{5}{|c|}{ Effects Specification } \\
\hline & & & S.D. & Rho \\
\hline \multicolumn{3}{|c|}{ Cross-section random } & 0.189945 & 0.5073 \\
\hline \multicolumn{3}{|c|}{ Idiosyncratic random } & 0.187182 & 0.4927 \\
\hline \multicolumn{5}{|c|}{ Weighted Statistics } \\
\hline R-squared & 0.620061 & \multicolumn{2}{|c|}{ Mean dependent var } & 0.588978 \\
\hline Adj. R-squared & 0.581292 & \multicolumn{2}{|c|}{ S.D. dependent var } & 0.297922 \\
\hline S.E. of regression & 0.192778 & \multicolumn{2}{|c|}{ Sum squared resid } & 1.821004 \\
\hline F-statistic & 15.99364 & \multicolumn{2}{|c|}{ Durbin-Watson stat } & 1.386771 \\
\hline Prob(F-statistic) & 0.000000 & & & \\
\hline \multicolumn{5}{|c|}{ Unweighted Statistics } \\
\hline R-squared & 0.689195 & \multicolumn{2}{|c|}{ Mean dependent var } & 1.460465 \\
\hline Sumsquaredresid & 3.387320 & \multicolumn{2}{|c|}{ Durbin-Watson stat } & 0.745520 \\
\hline
\end{tabular}

Sumber: Hasil ouput Eviews versi 9 (data yang telah diolah) 